\title{
UNIVERSITY EDUCATION IN THE CONTEXT OF ECONOMIC DEVELOPMENT OF THE REGION AND ITS INTEGRATION INTO THE EUROPEAN EDUCATION AND SCIENCE SPACE
}

\section{Orshanskiy L.V.}

\section{INTRODUCTION}

Modernization of the national education system from the 90's of the XX century simultaneously started with the transformation of the statepolitical and socio-economic system of Ukraine and under the circumstances when new values were offered to the society: in the realm of ideology - pluralism and publicity, politics - multiparty and democracy, economics - competitive market relations. However, unfortunately, the proclaimed fundamental principles were not united into a single, holistic doctrine of the construction of a new state. Therefore, for the past 27 years, the proper conceptual theoretical basis has not been created, which would allow unite the efforts of different strata of society, its intellectual and material resources for the implementation of fundamental and effective changes in the socioeconomic sphere. Such situation is primarily explained by the lack of the development and reflection of the initiated and still incomplete reforms, the lack of national-state ideology and adequate concepts that objectively led to extremely high social losses, adverse political, economic and social consequences.

One of the conditions for emerging from the economic crisis is the development of innovation activities, accelerated use of science, techniques and technology, as well as the qualitative training of relevant staff. This can be achieved if the national innovation system is formed, where, in the aggregate of its elements (production, consumption, business, marketing research, state power and management structures etc.), science and education develop consistently and dynamically. On the other hand, Ukraine consists of many regions with specific features - historical, geographical, ethnic, resource, economic, social, cultural, etc. The development of innovation activities, introduction of the latest technologies, which in 
the long run will make it possible to overcome negative tendencies, are primarily related to the need for structural reforms of the educational sector. In particular, cardinal Higher education needs to be changed as it is the most important potential resource, which determines the directions of sustainable economic development of the region.

\section{Knowledge economy and sustainable development of regions}

In the modern world, the position of any state is determined by the level of economic development. At the end of the twentieth century. In the developed world, the transition to a new type of economy based on intellectual resources, science-intensive and information technologies began. Therefore, in the conditions of globalization and the transition to the information society, the innovative way of development of the national economy has no alternative. This applies both to the country as a whole and its individual regions.

Defining the strategic objectives of socio-economic development of the region as a complex system is impossible without clarifying the requirements for such development. In a broad sense, the development of any object is defined as a special kind of qualitative transformation, which leads to the emergence of something new; it is a "process which results in a change in the quality of something, the transition from one

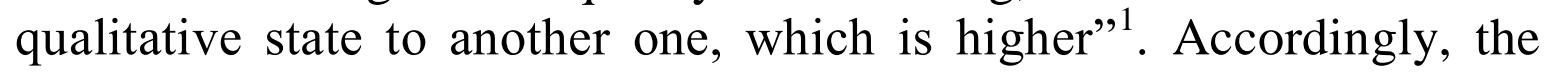
definition of "development of the region" will be considered as a complex process of changing its ecological, economic, social, spatial, political, and spiritual and cultural spheres, which leads to qualitative transformations and, ultimately, changes in the living conditions of ordinary people.

This definition indicates the direction, but does not specify the nature of the region. Currently, many economists are proposing to ensure the very sustainable nature of development, considering it as one of the global problems of our time. The analysis of scientific literature has shown that the term "sustainable development» is not generally accepted. For example, some authors refer to sustainable development as economic growth, which provides satisfaction of the material and spiritual needs of present and future generations while

${ }^{1}$ Словник української мови: в 11 т. / ред. кол. І. К. Білодід (голова) та ін. Київ: Наукова думка, 1970 - 1980; Т. 8: П - Р. С. 92. 
preserving the balance of historically formed ecosystems ${ }^{2}$. Others define sustainable grows as a stable socio-economic progress that does not destroy its natural basis ${ }^{3}$. The third, under the constant development of a complex socio-economic system (including the region), is a stable improvement in the quality of life of the population within the limits of the economic capacity of the biosphere, the excess of which leads to the destruction of the natural mechanism of environmental regulation and its global change ${ }^{4}$.

Based on the analysis and generalization of literary sources we have identified the requirements that characterize the socio-economic development of the region: 1) complexity - is characterized by positive tendencies in the transformations of all the main structural components of the "region" system; 2) proportionality means the achievement of certain relations between the spheres of a complex socio-economic system "region"; 3) safety - is characterized by factors of safe development of the main spheres of life of the region; 4) efficiency - is determined by comparing the performance of the system with the cost of resources to achieve these results; 5) Innovation - involves the development of all spheres of life in the region, based on the implementation of qualitatively new processes in the economy, associated with the transition from the lower technological order to the higher, which, in its turn, provides a sharp acceleration of economic growth.

The last requirement, the innovation of regional development in today's political and economic conditions is primarily due to the globalization of the world economy. The construction of an innovative model of development involves diversification of the economy, where the leading role belongs to new branches of knowledge and high-tech spheres of production. Moreover, according to M. Dmytrenko, the share of high-tech sector and knowledge economy in the gross domestic product should be at least $30 \%$ (now about $12 \%$ ), the contribution of the innovation component to the annual growth of the gross domestic product (GDP) - not less than $4 \%$ (today day does not

${ }^{2}$ Гринів Л. С. Екологічно збалансована економіка : проблеми теорії : монографія. Львів: ЛНУ ім. І. Франка, 2001. 240 с.

${ }^{3}$ Голубець М. А. Розвиток «сталий» чи «збалансований»? Украйнський географічний журнал. 2006. № 2. С. 66-69.

4 Герасимчук 3. В., Поліщук В. Г. Стимулювання сталого розвитку регіону : теорія, методологія, практика : монографія. Луцьк : РВВ ЛНТУ, 2011. 516 с. 
exceed $1,5 \%$ ), and state expenditures for scientific activity amount to at least $2-2,5 \%$ of GDP (now $0.2 \%)^{5}$.

Hence, the modern development of the economy is determined by the intensive growth of the level of intellectualization of both labor and means of production, which allows to create new qualitative competitive goods and services with a high share of value is added. The decisive element in the creation of such products is the knowledge and bearers of this knowledge, which form the intellectual capital of the country. The economy of knowledge is a non-alternative strategic direction for the development of both society and the state as a whole. For Ukraine, the transformation of the outdated raw material economy into the modern one is a priority, therefore the development and support of domestic high-tech industries should become an important part of the long-term process of building a competitive innovative economy - the knowledge of economy. Therefore, for sustainable development of the Ukrainian economy, it is necessary to use all possibilities of existing innovative economic mechanisms, in particular clusters, technological platforms, technology parks, start-ups, etc. These forms should be based on the combination of national and regional developmental aspects and fulfilling the following tasks: 1) to create a coherent system for the introduction of scientific research into production, which includes research, technological development, introduction into production, production and its successful promotion on the domestic and on the world markets; 2) create favorable conditions for attracting domestic and foreign investors to finance innovative projects; 3) to establish an industrial production of high-tech, competitive on the world market of products; 4) to create highly effective methods of control, analysis and protection of the environment; 5) to develop the material and technical basis of scientific research of an innovative nature; 6) coordinate scientific developments, their scientific and technical and technological expertise, as well as provide monitoring of innovation and investment activities in accordance with the priority economic directions; 7) to carry out training, retraining and professional grows of specialists for effective work in the conditions of the modern market of production and services ${ }^{6}$.

5 Дмитренко М. Інноваційний розвиток України в контексті впровадження нових знань. Освіта регіону. 2018. № 4. URL: http:// social-science.com.ua/ article/633

6 Про інновації та економіку знань. Міністерство економічного розвитку i торгівлі України. 24 листопада 2015 p. URL: http://new.me.gov.ua/content/proinnovacii.htm 
Viewing the last task, the introduction of innovative forms and mechanisms of sustainable development of the region requires the corresponding quality of human capital both in terms of the professional qualification level of the population and improvement of its economic consciousness, which testifies to their ability to master innovative processes. The new innovative strategy of economic development is realized taking into an account national, historical traditions, the mentality of the population, its culture, originality and uniqueness, which fit into the national innovation system, increasing its internal potential.

The growth of the role of human capital as a key factor in economic development is due to the fact that the level of competitiveness of a modern innovative economy is largely determined by the quality of professional staff, the degree of their socialization, communicativeness and creativity. At the moment, no state will be able to maintain its competitive position in the world of economy in a long run at the cost of cheap labor and saving on the development of the educational sector. Therefore, the prerequisite for the innovative development of the domestic economic sphere is the formation of a new economy based on knowledge that increases the quality of training and, formed with knowledge, expanding the employment of highly skilled staff. In the development of a modern economy, new knowledge becomes a dominant factor in production, and traditional factors - natural resources, labor where land and capital become secondary. So, the main factor of economic growth is new knowledge, and the obligatory condition is considered to be their effective use.

In its turn, a high level of new knowledge requires a radical reform of education, which should become a prerequisite for the development of society, the movement towards an innovative economy. In this context, attention is drawn to the scientific work of the famous English teacher, professor Bryan Simon "Society and Education", which reveals the main social functions of education based on the concrete historical approach, reveals the problems of educational processes in the period of 70-80 years of XX century. In particular, B. Simon substantiates the important role of education in the modern world and expresses the view: since a person changes the world around him, the entire historical process should be regarded as educational, and education - as a means of forming a person within society. The scientist argues that education as a factor in culture should be aimed at the fullest possible realization of 
the potential abilities of the individual. Education is essential for the development of both an individual in particular and whole society in general. By setting specific examples, he proves that, in combination with other factors, education is a powerful determinant of social and economic change. B. Simon believes that the understanding of the relationship between education, society and economy is changing over time, and the level of optimism or pessimism existing within depends on the economic situation: views on the importance of education are supported during the periods of economic recovery, and in the period of economic decrease - on the contrary ${ }^{7}$.

\section{Socio-economic character of higher education in the conditions of globalization}

Recently, the concept of education of the late XX - early XXI century. significantly expanded and deepened, reproducing the peculiarities of contemporary social development, in which its socioeconomic, transformational, innovative, and its stabilizing meaning significantly became considerable. In this context O. Karpenko, for example, expresses the view that education is a powerful factor in the transformation of the environment and society ${ }^{8}$. V. Kolesnyk observes that education today is a major, strategic factor not only in the socioeconomic, intellectual and spiritual development of society, but also in the decisive factor in its survival and security ${ }^{9}$. Importance and innovative role of education in the XXI century V. Kremen substantiates outlining in various ways, emphasizing that modern life puts a number of challenges ahead of education: the need to provide high human functionality in conditions of rapid changes in knowledge and technologies, awareness of the realities of a globalized world; the ability to live and act in similar circumstantial situations ${ }^{10}$.

${ }^{7}$ Саймон Б. Общество и образование / под. ред. В. Я. Пилиповского. Москва : Прогресс, 1989. 199 с.

8 Карпенко О. М., Бершадская М. Д. Высшее образование в странах мира : анализ данных образовательной статистики и глобальних рейтингов в сфере образования. Москва : Изд. МГУ, 2009. 244 с.

${ }^{9}$ Колесник В. Ю. Освітні програми нового покоління Свропейського Союзу як правовий механізм впливу на євроінтеграційні процеси у сфері освіти. Вісник Чернівецького факультету Національного університету «Одеська юридична академія». 2015. № 2. С. 7-17.

10 Кремень В. Освіта і наука в Україні - інноваційні аспекти. Стратегія. Реалізація. Результати. Київ : Грамота, 2005. 448 с. 
It should be borne in mind that education in the XXI century - is not only a way of retransmission of the finished knowledge and a means of education of the individual. In the present age of globalization and high technologies, it is a factor in social stability, economic well-being of the country, its competitiveness and national security. The field of higher education and research is the foundation of a well-developed society based on knowledge ${ }^{11}$. Modernization of knowledge about the essence and importance of education P. Kryazhev's view: education gives humanity the opportunity to develop in the direction of ideals of peace, freedom, social justice ${ }^{12}$. This scientific approach extends to V. Kudin, who relates education with the most important human values. He emphasizes that education and all acquired culture, human spiritual forces must be directed at the creation and perfection of both man himself and every nation. Education is intended to instill a set of those ideals that contribute to the development of health, bring true spiritual, moral satisfaction, raise a person to a new quality ${ }^{13}$. In the same work, N. Nichkalo emphasizes that education is the most effective, promising way and, at the same time, the key to the progress of mankind in the third millennium, as the general definition of prominent scholars, politicians, economists, educators and public figures in many countries of the world. Education is the main factor in the advancement of highly developed civilized states, the formation of high spirituality, intelligence, culture, a sense of social responsibility for the results introduced by new technologies, for all of that what is left to descendants by each generation ${ }^{14}$.

S. Sysoeva adheres to similar scientific positions concerning the nature of education, asserting that today education is perceived as a special sphere of social life, a unique system, a socio-cultural phenomenon, an essential characteristic of human civilization. The new educational model of a post-industrial society must be in line with realities, global integration processes, and global changes that take place

11 Кремень В. Освіта і наука в Україні - інноваційні аспекти. Стратегія. Реалізація. Результати. Київ : Грамота, 2005. С. 158.

12 Кряжев П. В. Структура вищої освіти в країнах Західної Свропи на межі XX - ХХІ століть. Педагогічний альманах. Херсон, 2008. Вип. 3. С. 177-183.

${ }^{13}$ Професійна освіта в зарубіжних країнах : порівняльний аналіз : монографія / за заг. ред. Ничкало Н. Г., Кудіна В. О. Київ : Вибір, 2000. С. 6-7.

${ }^{14}$ Там само. С. 45. 
in all spheres of life ${ }^{15}$. In an inextricable connection, the question of civilization development of society with the education of its citizens is considered by V. Ognevyuk, stating: "The phenomenon of education is determined by its influence on the development of man and society. XIX and XX centuries. convincingly proved that only the society that cares about the creation of conditions for the personal development of man, for its socialization and identification as a member of this society, can ensure the reproduction of civilization principles of its functioning and development" $"$.

The considered views of scientists on education naturally relate to its important component - higher education. Higher education in the UNESCO document "International Standard Classification of Education" is interpreted as education, which "ensures active social position of the subject, successful intellectual activity in the chosen sphere of public life; it is carried out not on the dictation, but on scientific principles"17.

Outlined by modern science, higher education is defined as the level of education, which is based on secondary or vocational education and is aimed at satisfying the needs of the individual in the fundamental scientific, general cultural and special education ${ }^{18}$. The higher education system also reflects the demands of society on the formation of specialists of high qualification level. According to M. Fitsula: "The system of higher education provides fundamental scientific, professional and practical training, obtaining citizens of educational and qualification levels in accordance with their vocations, interests and abilities, and improving scientific and professional training" "That is, qualitative orientation into practice allows higher education to successfully solve such diverse tasks: 1) to provide broad education and obtain professional qualifications, including the acquisition of a certain set of competences and skills, for all citizens of the country, so that they are competitive in the labor market; 2) to identify, select and prepare the most capable

${ }^{15}$ Сисоєва С. В. Освіта як об’єкт дослідження. Шлях освіти. 2011. № 2. С. 5-11.

16 Огнев'юк В. Філософія освіти в структурі наукових досліджень феномену освіти. Шлях освіти. 2009. № 4. С. 2.

${ }^{17}$ Бондаренко Е. Н. Профессиональное педагогическое образование в зарубежных странах на современном этапе : монография. Минск : Тесей, 2008. С. 49.

18 Дмитриченко М. Ф., Хорошун Б. І., Язвінська О. М. Вища освіта і Болонський процес : навч. посіб. Київ : Знання України, 2006. С. 401.

${ }_{19}^{19}$ Фіцула М. М. Педагогіка вищої школи : навч. посіб. 2-е вид., допов. Київ : Академвидав, 2014. С. 83. 
citizens, taking into an account their specific abilities in different fields of professional activity.

The fundamental position of $\mathrm{M}$. Mikhalchenko is that higher education is a powerful factor in economic growth and the development of political systems, the basis for improving the well-being of people. It is based on the experience of world and national educational systems and the acquired scientific knowledge and technical achievements. For the correspondence of higher education to modern requirements of great importance are various forms of interethnic integration of science and education, the continuity of education ${ }^{20}$.

Hence, higher education acts as a value itself and as a means of achieving other goals. In this context M. Mikhalchenko, emphasizing the value of education for each individual, identifies certain types of its manifestations: economic, social, moral and psychological. In economic concept - it turns out that highly qualified labor, which, accordingly, requires higher education, each time paid for better than less qualified. The social value of education is associated with a person receiving a higher status in the social hierarchy. Moral-psychological value interacts with the self-affirmation of a man, the formation of confidence in his powers, awareness of its significance ${ }^{21}$.

Let's dwell on the system of university education in the context of implementation of the provisions of the Bologna Process and integration into the European scientific and educational space.

It is well known that the system of higher education is a complex of different types and types of institutions of higher education (HEI). According to modern European integration tendencies, one of the main tasks of reforming the national higher education is the restructuring of the HEI network. The basis of this network should be sufficiently large, technically equipped, staffed with highly skilled scientific and pedagogical staff, financially stable, autonomous HEI. These educational or educational institutions in accordance with the prescribed procedure and in accordance with the license and accreditation, implement higher education programs and carry out scientific activities ${ }^{22}$.

${ }^{20}$ Модернізація системи вищої освіти: соціальна цінність і вартість для України: монографія / Михальченко М. І., Андрущенко В. П., Бульвінська О. І. та ін. Київ: Пед. думка, 2007. С. 8.

${ }^{21}$ Там само. С. 173.

22 Дмитриченко М. Ф., Хорошун $\quad$ Б. І., Язвінська О. М. Вища освіта і Болонський процес : навч. посіб. Київ : Знання України, 2006. С. 401. 
Among the different types of HEI, the determining role belongs to the universities in which the complex of such functions is systematically implemented: educational (preservation, transfer of knowledge, science, culture); research (development of knowledge, research work); professional (training of highly skilled specialists); cultural (formation of intellectual abilities); humanistic (awareness of the values of mankind, civilizations and cultures of the world $)^{23}$.

Various aspects of the development of the modern European system of higher education, in particular university studies, are researched by many national scholars: V. Andrushchenko, A. Boyko, M. Yevtukh, V. Zubko, V. Kremin, S. Kurbatov, O. Lokshyna, N. Nichkalo, and others. They analyze the topical problems of higher education in close relationships, considering: modern dimensions of education as a scientific concept; the role of higher education in the world and European educational space; factors of influence on modern higher education, trends of its development; the peculiarities of reforming higher education on the principles of the Bologna Declaration, its achievements, problems and perspectives, etc.

In the process of analyzing European and world pedagogical thoughts and practices it became clear that the concept of university education at the beginning of the XX century tried to develop a wellknown scientist, a philosopher and publicist S. Hessen. Relevant consideration of the conceptual provisions expressed by them is expedient, since in the European educational conditions by the end of XX - beginning of the XXI century became very popular. Here are some of his ideas and statements about higher education and the university as an integral part of it.

Analyzing numerous problems, S. Hessen primarily proceeded from the recognition of the close relationship between the concepts of «education» and «culture». So, the components of culture, according to the scientist are: education (science, art, morality, religion), citizenship (law, state) and civilization (economy, technology). These interrelated components, he considers cultural values, in which the education and culture of the individual are inseparable. As many types of cultural property exist, there are so many types of education. Education by its very nature can never be completed. A person becomes educated

${ }^{23}$ Бондаренко Е. Н. Профессиональное педагогическое образование в зарубежных странах на современном этапе : монография. Минск : Тесей, 2008. С. 58. 
throughout his life. According to S. Hessen, only an uneducated person can argue that it completely solves the problem of education for itself. According to the scholar, the ways of education are very diverse: read a book, listen to a concert or a lecture, a theatrical performance, an occasional meeting, etc. However, special independent institutions like libraries, museums, higher educational institutions, and others play the most important role in the educational journey of a $\operatorname{man}^{24}$.

S. Hessen expressed a distinct vision of the theory of the university, as evidenced by some of the current relevant provisions of his fundamental work «Fundamentals of Pedagogy. Introduction to Applied Philosophy», in particular: 1) the goal of higher education - the mastering of scientific research methods; 2) the organization of the university must meet the requirements of freedom of choice: university, faculty, curriculum, teachers; the one who studies should be given the opportunity to move from one faculty to another, from university to university; 3) the university is the source of science: the more successful a person has mastered the university course, the more she joined the scientific thought, the greater it is the need to return from time to time to the university in order to plunge into the atmosphere of science, which has gone onward in that time, to update the experience of their practical activity; 4) the higher scientific school should be primarily a source of scientific research, its teacher - an active researcher, an independent scientist, who expands the sphere of consciousness by his scientific work, a student - a participant in the research work of a teacher, a novice scientist, that is why the higher scientific school or university is inextricably unity of teaching and research; 5) the professor is the better, the higher his level as a scientist; the professor's oratory's manifestation is not in the lightness and polishing of the style of speech, but in his ability to reason during the presentation, to open the lectures on new evidence and shades of thoughts; 6) self-management of the university, or its autonomy, constitute the essence of the university as a source of new scientific knowledge; 7) the ideal nature of the university is characterized by the principles of completeness of scientific knowledge, freedom of teaching, learning and self-management; 8) the significance of the lecture is not that it replaces the reading of books, but that it

24 Гессен С. И. Основы педагогики. Введение в прикладную философию. Москва: Школа-Пресс, 1995. С. 217. 
induces reading and independent study; 9) freedom of teaching and learning is a natural element of the university ${ }^{25}$.

Conceptual provisions of S. Hessen have gained modernity in the demands of democratization, mobility, autonomy, humanization, and strengthening the research functions of university education. Modern Ukrainian scholars (O. Bondarenko, M. Dmytrychenko, V. Kremen, V. Kurylov, S. Kurbatov, V. Lugovyi, G. Horuzhii, etc.) emphasize the most significant features of the university as HEI. In their view, the conceptual provisions are that the university in the system of European higher education is building its activity on the principles of freedom and autonomy. In this case, the principle of university autonomy is considered as: 1) the indicator of the development of democracy in the country and a certain HEI; 2) the norm of the institution's management, which ensures a certain accountability, compliance with regulatory and legal acts; 3) the degree of self-management in the HEI; 4) a set of rights and responsibilities, a combination of academic freedom of the HEI with responsibility to society and the teaching team ${ }^{26}$.

The Charter of European Universities, which was adopted in 1988 and signed by the rectors of 388 universities, is important for the development of universities' activity based on the principles of autonomy and freedom. In September 2011, an official ceremony for the celebration of the 23rd anniversary took place in Bologna, Italy and signing the Charter of the European Universities happened in the oldest European University. In general, it was signed by representatives of about 800 universities in the world.

At the end of XX - beginning of the XXI century in many countries in Europe there has been a social situation due to such stimulating factors of higher education reform as globalization, internationalization, integration, the transition of industrial society to the post-industrial and information society of knowledge.

According to K. Astakhova's recognition the globalization is characterized by the creation of a world economy as an integral organism, the integration of cultural ties, the emergence of interdependence of countries, the expansion of contacts between people

25 Гессен С. И. Основы педагогики. Введение в прикладную философию. Москва: Школа-Пресс, 1995. 447 с.

${ }^{26}$ Хоружий Г. Ф. Вища освіта на шляху оптимізації. Шлях освіти. 2011. № 4. C. 23. 
of different nationalities, the activation of the activities of international and supranational structures ${ }^{27}$. According to O. Bondarenko, globalization is an objective process, as a result of the intensive development of world economies and countries, their openness for interaction, integration, exchange of goods, services, cultural values, educational standards, financial resources, etc. At the same time, globalization is a contradictory process that has advantages (increased volumes of production and goods market, expansion of the world market, etc.), and also contains threats and risks (increasing the gap between the poor and the rich, rising unemployment, forced migration, devaluation of moral values, etc.). Therefore, the important task of the countries is to minimize its negative aspects and use of globalization opportunities for the benefit of people, humanity ${ }^{28}$.

The scientist K. Astakhova observes that the reflection of the processes of globalization in the field of higher affects above all its aspects: internationalization strategies; quality assurance; problems of transnational, regional and interregional cooperation; information and communication technology training; improving the level of access to higher education, etc. She expresses the opinion that globalization generates the need for radical changes in education, bringing it in line with new social demands, patterns and trends of the new century. Higher education of the XXI century requires dynamic action and comprehension of educational problems at the level of theory and practice. Modern higher education should form the ability of the person to global thinking, the adoption of fundamental values, a deep look at the world, its vision is not in the fragmentary, but in its entirety, the ability to creativity, manifestation in the unity of reason and conscience, reason and emotions, etc ${ }^{29}$.

V. Zubko attaches great importance to higher education as a means of forming a new generation of specialists in the period of

27 Астахова К. В. Вища освіта в умовах сучасного етапу глобалізації : потреба кардинальних змін. Вища освіта України. 2010. Том I (19). Додаток 4. Тематичний випуск «Вища освіта України у контексті інтеграції до європейського освітнього простору». С. 29.

${ }^{28}$ Бондаренко Е. Н. Профессиональное педагогическое образование в зарубежных странах на современном этапе : монография. Минск : Тесей, 2008. С. 73.

${ }^{29}$ Астахова К. В. Вища освіта в умовах сучасного етапу глобалізації : потреба кардинальних змін. Вища освіта України. 2010. Том I (19). Додаток 4. Тематичний випуск «Вища освіта України у контексті інтеграції до європейського освітнього простору». С. 31-32. 
globalization. The scientist notes that on the threshold of the third millennium, the high school is rapidly and sometimes transformed dramatically. Changes in the means of production, their own educational problems make it oriented towards global social processes, among which: the political restructuring of the world; formation of a democratic organization of the world community; creation of a new concept of national security; strengthening interdependence and interaction of countries; rejection of economic and cultural self-isolation, etc ${ }^{30}$. Similar is the scientific position of A. Sbruva, who points out that globalization as the main characteristic of the development of human civilization at the beginning of the XXI century predetermines fundamental transformations not only in the spheres of economics, politics, science, information technologies, but also in education. Under the influence of globalization on the transformation of the cultural and educational sphere of human life, the following concepts are combined: internationalization of production, trade, finance; international mobility of people (students, immigrants, refugees, tourists); development of diaspora communities; global circulation of ideas and concepts; initiatives of international organizations; formation of educational space ${ }^{31}$.

The scientific position expressed by A. Sbruva, scholar N. Avschenyuk, who in the article «Socio-economic determinants of the development of transnational higher education at the turn of the $\mathrm{XX}-$ XXI centuries», confirms the strengthening of the role of higher education in the modern conditions of the development of civilized countries, illustrating it by the relevant facts. The scientist informs: Studies of the International Labor Organization have found that in Canada, for example, $70 \%$ of newly-created occupations require specialists with higher education. The United States is not able to prepare the required number of highly skilled workers, especially for highly intensive sectors of the economy, although it has one of the most extensive HEI networks. Therefore, there was a phenomenon of so called competition of the countries for attracting the best students to study from different corners of the world, the phenomenon of

${ }^{30}$ Сучасні системи вищої освіти : порівняння для України / за заг. ред. В. Зубка. Київ : Вид. дім «КМ Асасіетіа», 1997. 290 с.

31 Сбруєва А. Болонський процес : пошуки шляхів підвищення конкурентоспроможності європейської вищої освіти. Шлях освіти. 2002. № 1. С. 18. 
accelerated development of transnational higher education. There is a rapid growth of international academic mobility of students. One of the most important motivations in obtaining higher education in a transnational model is to increase the employment opportunities on favorable conditions for a specialist. Graduates of prestigious foreign universities have priorities in the labor market both in developing countries and at the place of study in high-growth countries ${ }^{32}$.

Today, many countries have started processes of reorganization of higher education systems that meet the requirements of the global economy, international quality standards of production. This is manifested in a number of factors: the unification of educational and scientific levels; change of priorities in the formation of educational programs and curricula in the direction of humanities, autonomy and financial independence of universities; ensuring mobility of students and teachers; compulsory study of English; improving the quality of vocational training, etc. Globalization has changed the goals and orientations of higher education in many countries of the world, despite the state of their economic development. If in the past universities were considered as an integrative component of the forces of national formation of the state, now they are associated with the production of highly skilled professionals for the global labor market ${ }^{33}$.

Another important concept is the modern processes of internationalization of education, which, in the broadest sense, spread knowledge, competences and values that have universal application and global recognition. Internationalization manifests itself in the international orientation of educational programs offered by universities, and globalization contributes to overcoming the boundaries and frames of national education systems. At the same time, one should agree with the conclusions of $\mathrm{N}$. Avshenyuk concerning the development of transnational and local universities: "There should be a thorough regulatory basis for their activities, since the unsettled nature of this sphere may also have negative consequences over time: the weakening of the role of local institutions of higher education, the enhancement of labor migration, that can hamper the development of national economies

32 Авшенюк Н. Соціально-економічні детермінанти розвитку транснаціональної освіти на зламі XX - XXI століть. Порівняльна професійна педагогіка. 2011. № 1. C. 52-61.

\footnotetext{
${ }^{33}$ Там же. С. 57.
} 
of individual countries"34. K. Korsak outlines the tendency of internationalization of higher education through the implementation of such approaches: introduction to the curricula of "international disciplines' (international law, international trade, etc.); realization of foreign language study plans for foreign students; application of curricula that lead to the combination or duality of diplomas and their recognition in other countries ${ }^{35}$.

One of the decisive consequences of globalization was the emergence of a world and European educational space. In the scientific work of N. Skotnoyi "Personality in the split civilization" it is noted that the educational space is a subsystem of the socio-cultural environment, a set of historically formed factors, circumstances, situations, that is, specially organized pedagogical conditions of development the personality. Under this concept, the totality of material, spiritual, emotional and psychological conditions in which the educational process is reproduced, and factors that contribute or hinder its effectiveness is understood $^{36}$.

The world educational space is considered to be a collection of all educational institutions, scientific and pedagogical centers, governmental and public educational organizations in different countries, geopolitical regions, as well as the interaction and interaction of these institutions in the conditions of intensive internationalization of various spheres of public life ${ }^{37}$. The world trends in the development of modern higher education are embodied in the UNESCO Program "Education: A Hidden Treasure" - a humanization, humanization, continuity, fundamentality, efficiency, mass media, technology and informatization.

European educational field - part of the world, limited to the region of Europe. The concept of "European education" is conditionally considered in three aspects: first, education in Europe; secondly,

34 Авшенюк Н. Соціально-економічні детермінанти розвитку транснаціональної освіти на зламі XX - XXI століть. Порівняльна професійна педагогіка. 2011. № 1. С. 60.

${ }^{35}$ Корсак К. В. Світова вища освіта. Порівняння і визнання закордонних кваліфікацій і дипломів : монографія / за заг. ред. Г. В. Щокіна. Київ : МАУП-МКА, 1997. 208 c.

${ }^{36}$ Скотна Н. Особа в розколотій цивілізації : освіта, світогляд, дії : монографія. Львів : Українські технології, 2005. 384 с.

37 Астахова К. В. Вища освіта в умовах сучасного етапу глобалізації : потреба кардинальних змін. Вища освіта України. 2010. Том I (19). Додаток 4. Тематичний випуск «Вища освіта України у контексті інтеграції до європейського освітнього простору». С. 34. 
education about Europe; thirdly, education for Europe. Hence, the European Commonwealth is considered as the only historical, social, economic, ecological, cultural, educational system. One of the tasks of education is the formation of awareness among the younger generation about a common European affiliation, and value education should be based on the ideas of democracy and human rights. Common European values included respect for the lives and rights of others, responsibility, solidarity, openness to other peoples and cultures, tolerance, the will to peaceful coexistence and the preservation of peace ${ }^{38}$.

The category "European educational space" has become integrated to interact with the concept of "a single European research area" after the European Commission published in January 2000 an appeal "On the European Research Area"39. The appearance of this document was aimed at creating the best conditions for conducting research in order to achieve world leadership in education in Europe. The document proposes to strengthen the scientific cooperation of the researchers and scientists of the participating countries and to improve the coordination of research within the EU without excessive bureaucracy and significant funds.

Hence, higher university education of the late XX - early XXI centuries. has gained certain tendencies of modernized development in the world and European educational space. The existence of these trends is seen in the quest for its democratization, the right to higher education for all, the significant impact of socioeconomic and political factors on higher education, the development of the market for educational services, the expansion of the network of universities, the search for a compromise between centralization and a certain autonomy in management higher education, in updating educational programs, curricula, etc.

\section{University education in Ukraine and Bologna process}

Transformational trends in higher university education in Europe have become the subject of discourse by many Ukrainian scholars: M. Dmitrichenko, V. Zubko, G. Kalinicheva, A. Sbrueva, M. Stepko,

38 Тараненко І. Г. Нові орієнтації у змісті соціально-політичної освіти європейських країн. Педагогічні інноващії : iдеї, реалї̈, перспективи. Київ, 1998. C. $94-98$.

39 European research area (ERA). URL : https://ec.europa.eu/info/research-andinnovation/strategy/era_en 
G. Tereshchuk, G. Horuzhii, and others. In general, they state that globalization, internationalization, integration, the transition to an information society, in which the new paradigm of economic relations is knowledge, have significantly influenced the European educational platform as a component of the world's space.

The tendencies of the development of higher university education in Europe are as follows: 1) extension of the period of compulsory general education; obligatory vocational education after school, including the transition to mass higher education; 2) the formation of a system of continuous education throughout life; 3) diversification of HEI types, expansion and deepening of their tasks and functions; 4) strengthening the interaction between higher education and employers; 5) creation of scientific and educational complexes as a form of integration of science, education and production as a specific for higher education; 6) the diversification of the system of studying and internship abroad; 7) provision of conditions for the mobility of students and teachers; 8) global informatization of the educational process, introduction of new digital technologies; 9) improving the quality of higher education and the readiness of applicants to perform professional functions; 10) increasing the requirements for the professionalism of teachers and improving the conditions of their work; 12) introduction of innovations in management and diversification of funding for higher education institutions.

The idea of creating a European University Community and a Single European Higher Education Area is primarily linked to the signing of the Bologna Declaration adopted on June 19, 1999 (Bologna, Italy). Ministers of 29 European countries responsible for higher education signed a joint declaration "On the European Higher Education Area", as evidenced by the creation of a single European educational space. The declaration stated that the European integration process, thanks to its special achievements, becomes a tangible and significant reality for the EU. Politicians, scholars, and the public are more and more aware of the need to build Europe's future through the use and strengthening of its intellectual, cultural, social, scientific and technological potential. The primary importance of education and educational cooperation for the development and consolidation of stable, peaceful and democratic societies is universally recognized. It was noted that "the viability and effectiveness of any civilization is measured by its cultural influence on other countries. An important task is to increase the 
international competitiveness of the European higher education system, to create a system that would be attractive to the whole world and be in line with the peculiarities of cultural and scientific traditions" 40 .

It was the Bologna Process that initiated the structural modernization of national higher education systems, including Ukrainian, recognizing the objective need for integration actions. This process has its own background, which distinguishes three periods: the first covers 1957-1982, the second - 1983-1992, the third - 1992-1998. In each of these periods, important events were held - joint conferences of Ministers of Education, meetings, consultations, discussions on which numerous normative-legal documents (the Grand Charter of Universities, treaties, conventions, declarations, programs of joint actions, etc.) were developed and approved, aimed at the development of a single pan -European approach to higher education. In particular, in 1967, the first European Conference of Ministers of Education took place, which initiated a complex process of developing a unified European approach to higher education as a system and result. The Conference of Ministers of Education in 1971 agreed on the issues of mutual recognition of diplomas, cooperation in the development of the second higher education, the creation of a European center for higher education, etc., proposed a number of international projects to strengthen the relationship of higher education and production structures. In 1986, preparing for the 900th anniversary, the leadership of the oldest in Italy Bologna University appealed to all universities in Europe with a proposal to adopt the Grand Charter of Universities (Magna Charta Universitarum). The idea was enthusiastically picked up, and during the anniversary celebrations in 1988, the document, which proclaimed the universal and eternal values of university education, as well as the need for close ties between them, were signed by rectors of 80 universities. The Great Charter of European Universities proclaimed the fundamental principles of recognition of universities by the centers of culture, knowledge and research, the main intellectual centers of society. Significant role played by the Lisbon Convention (1997), which was concerned with the harmonization and recognition of qualifications belonging to European higher education. The Sorbonne Declaration (1998) first raised the question of the formation of an open European

${ }^{40}$ Дмитриченко М. Ф., Хорошун $\quad$ Б. І., Язвінська О. М. Вища освіта і Болонський процес : навч. посіб. Київ : Знання України, 2006. С. 327-328. 
space in higher education, a predominant orientation towards a two-tier structure, the need for common recommendations for the convergence of national systems of higher education, etc.

The emergence of the Bologna process is a response to the general tendencies of the world development of the late XX - early XXI centuries, objectively logical process of convergent reforms in European higher education. Major changes in the context of the Bologna process include: 1) adoption of a higher education system based on two main levels of education: basic - undergraduate (3-4 years of study) and full - magistracy (1,5-2 years of study);2) the introduction of a credit system to account for the complexity of educational work; credit units can be applied at all levels of higher education, including continuous; 3 ) introduction (in order to ensure the employment of university graduates in the European labor market and increase the competitiveness of universities), mutually agreed and unified application for diplomas that are comparable amongst all over the European space; 4) quality control of higher education through the organization of accreditation agencies and monitoring structures; 5) ensuring mobility through removing barriers for students to access education, freedom of movement for educational services, and for teachers to increase their research capacities, enriching European experience; 6) growth of cooperation in the development of educational programs and curricula, interaction between HEI, design of mobility schemes and integrated training and research programs, quality control of education, etc.; 7) strengthening of the European dimension of higher education, especially in the field of scientific research; 8) securing the employment of graduates, orientation of HEI for the final result of professional training, is closely connected with the needs of the European labor market; 9) developing the attractiveness of the European education system, increasing the interest of Europeans and other citizens in higher education, and attracting more students from other regions of the world to Europe.

The urgency and complexity of the problems of the Bologna process resulted in their further detailed discussion at meetings, seminars and conferences of ministers of European countries, the subject of which was the analysis of the status of tasks, additions, clarifications, and outline of the prospects. In particular, in the period after the Bologna Conference and by October 2003, 23 events on European cooperation in the field of education were carried out on the implementation of the 
provisions of the Bologna Convention on the standardization of approaches to the organization of educational process, the functioning and development of higher education in the EU, the expansion of the European educational space to other states, etc.

The development of approaches to solving the Bologna process was devoted to Berlin (Germany, 2003) and Bergen (Norway, 2005) conferences. In particular, in the Communique of the Berlin Conference - "Creation of a European High School Space" - emphasis was placed on the quality of higher education, the responsibility of each individual educational institution. An important decision was made to expand the boundaries of the modern system of higher education from two levels to three, including a doctoral degree as a third educationalscientific level. It is decriminalized that in the countries participating in the Bologna process there should be one doctor's degree - "doctor of philosophy" $(\mathrm{PhD})$ in the corresponding areas of knowledge (natural sciences, socio-humanitarian, economic, engineering, pedagogical, etc.). The important role of IHE in the implementation of the principle of human learning throughout life is noted. The unity of the European Higher Education Area and the European Research Area as a whole have been recognized. A working group was established to strengthen interim control over the implementation of the tasks of the Bologna Convention.

At the Bergen Conference, particular attention was paid to the interaction between higher education and diverse research activities. The issues of further development of the principles of doctoral programs and ensuring an increase in the number of doctoral students were agreed upon. It was emphasized the need to develop a project to increase the perception of the Bologna process in other regions of the world.

The problems of the Bologna process, the state of their solution, achievements and difficulties are deeply analyzed in the scientific works of domestic scientists. Thus, V. Andrushchenko states that the Bologna process is a directed cooperation of European universities, institutes, schools, centers. Changes initiated by the Bologna Declaration should improve the quality of education, its competitiveness, attractiveness and demand in the European educational space $^{41}$. The development of higher education systems in foreign countries is described in detail and in various ways by the works "Higher education and the Bologna

${ }^{41}$ Андрущенко В., Молодиченко В. Академічна мобільність : проблема реалізації в Україні і в світі. Вища освіта Украӥни. 2010. № 1. С. 34. 
process", sponsored by M. Dmytrychenko, B. Horoshun, O. Yazvinska ${ }^{42}$. They analyze foreign higher education, the main factors of European integration in the educational sphere, the features of higher education systems in many countries, explain the essence of the Bologna process, the specific principles and means of its course. Particular attention is focused on the European Credit Transfer System (ECTS), its purpose, meaning and methodology. Scientists point out that ECTS is a system based on a systematic way of describing an educational program by assigning loans; it determines the students' educational load, which is necessary to carry out the tasks of the educational program. The content of the concept of "credit" used in the Bologna process is explained in detail. The system of credits enables to monitor the students' educational program, determine the necessary amount of student's work (lectures, practical classes, consultations, control tasks, types of independent work, forms of final evaluation, etc.). Credits are assessed for compulsory (normative) disciplines and optional courses, coursework and qualification papers or projects, educational and industrial practices, and other forms of educational activities provided for by the educational program.

The theory and technology of the convergence of educational systems in the European space attracted the scientific attention of the researcher G. Tereshchuk, who highlights the directions of transformation in the preparation of specialists of the XXI century: ensuring the transparency of educational programs; creating conditions for comparing educational programs in different universities and in different European countries; the implementation of the European Credit Transfer and Transfer System (ESTS) as a basic tool for academic discipline enrollment, worked out by students at other universities, etc. The content of education and the results of learning G. Tereshchuk relates with the increase of general cultural and functional competence, the formation of cognitive independence and activity of IHE graduates ${ }^{43}$.

Scientist A. Sbrueva, when considering the creation of the European Higher Education Area, attaches great importance to the system for monitoring the quality of education and IHE accreditation in each of the

${ }^{42}$ Дмитриченко М. Ф., Хорошун $\quad$ Б. І., Язвінська О. М. Вища освіта і Болонський процес : навч. посіб. Київ : Знання України, 2006. 440 с.

${ }^{43}$ Терещук Г. В. Зближення освітніх систем : теорія і технологія. Педагогічна $i$ психологічна науки в Україні : зб. наук. праць до 15-річчя АПН України у 5 т. Київ : Пед. думка, 2007. Том 1: Теорія та історія педагогіки. С. 157. 
countries participating in the Bologna Process and notes that the quality audit of higher education at the national level is sufficiently developed in the UK, Denmark, Sweden, France, Finland, is actively developing in Italy, Germany, Lithuania, etc., absent at the national level in Austria, Belgium, Greece, etc ${ }^{44}$.

Academic mobility, as part of the Bologna process, is devoted to research by $\mathrm{O}$. Vauulin and A. Umerova. Academic mobility is explained by academics as an opportunity for students, lecturers and administrative and managerial staff of IHE to "move" from one institution to another. It is understood that according to the recommendations of the Bologna Declaration, conducting a semester student in another IHE (mainly abroad) will give him the opportunity to access new quality programs, courses, research activities, and improve the knowledge of foreign languages. A high degree of academic mobility implies the availability of hostels, health insurance, funding sources, etc. Measures for mobility are associated with material support for mobility; strengthening of informing potential participants about the possibility of mastering separate courses and programs in other HEI; the development of normative-methodical and technological support ${ }^{45}$.

Not only educational trends and problems of the present are included in the circle of scientific interests of researchers of the future international associations but also the subject of discourse became future development issues of the education. In this context, the Conference of European Ministers of Education, which took place in Leuven (Belgium, April 2009), attracts attention. The issue of the future of European higher education for the next decade was actively discussed at the conference. The communique of this conference provides an overview of the main priorities for the European Higher Education Area up to 2020. The document proclaims that higher education, based on the principles of innovation, should make a significant contribution to the development of knowledge of Europe, to promote the socio-cultural development of different countries. This contribution is generated by objective conditions, in particular the need to overcome the main challenges of

${ }^{44}$ Сбруєва А. Болонський процес : пошуки шляхів підвищення конкурентоспроможності європейської вищої освіти. Шлях освіти. 2002. № 1. С. 18-21.

${ }^{45}$ Вауліна О. С., Умерова А. С. Академічна мобільність як складова Болонського процесу. Вища освіта України. 2010. Том I (19). Додаток 4. С. 61-66. 
today - globalization, rapid aging of the population, financial and economic crisis, man-made disasters, environmental problems, etc.

Noting the positive character of the modern European Higher Education Area (mobility, the transition to a three-tier education structure, the implementation of the Bologna Process, cooperation, etc.), ministers outlined the vision of what will be crucial in the development of higher university education in Europe by 2020. The following priority tasks were defined: ensuring equal opportunities for obtaining highquality higher education by different groups of the population; improvement of the educational environment, creation of proper conditions for education at all levels; expanding lifelong learning; implementation of the principle of student-centered learning; sustainable integration of learning and research; Further internationalization and deepening of mobility in educational and research activities; strengthening of interaction between state authorities, Institutions of High Education, students, employers; strengthening autonomy of universities; realization of cooperation in the system "university enterprise" quality control at the European level; further implementation of the tasks and provisions of the Bologna Convention, etc.

In March 2010, a conference of the Ministers of Education in Vienna and Budapest was held where the Integrated Higher Education Area (EHEA) was officially announced, an official EHEA website was created, and a forum was adopted, embracing the Bologna Policy Forum Statement. In April 2012, the Ministerial Conference in Bucharest (Bucharest Communiqué), which was responsible for higher education in 47 countries of the EHEA, was held, reviewed the achievements of the Bologna Process and agreed on future priorities for higher education in Europe, namely: increasing access to higher education; recognition of formal and informal learning; the need for additional investment in higher education for the future; ensuring its high level of financing; completion of the transition to a three-cycle higher education system (bachelor, master, doctor of philosophy); introduction of qualifications frameworks; improvement of the system of monitoring, implementation and application of European standards and recommendations for the quality assurance of higher education (ESG), etc ${ }^{46}$.

${ }^{46}$ Mobility for Better Learning. Mobility strategy 2020 for the European Higher Education Area (EHEA). Bucharest Ministerial Conference (2012). URL: http://www.ehea.info/uploads/(1)/2012\%20ehea\%20mobilit\%20strateg.pdf 
In Yerevan (Armenia), in 2015, the Conference for Ministers of Education and the Fourth Bologna Political Forum took place, which resulted in the adoption of the Yerevan Communique and the Declaration of the Fourth Bologna Policy Forum. One of the key events was the approval of the updated "Standards and Recommendations on Assurance Quality in the European Higher Education Area" (ESG), which more fully describes the internal quality assurance procedures and determines the relationship between the Bologna process and the quality of education. Standards and guidelines for quality assurance in the European Higher Education Area which are recommended for internal and external quality assurance systems in higher education, whose main objective is to promote a better understanding of the quality of teaching and learning, regardless of the boundaries between all stakeholders. It was emphasized that standards play a key role in the development of national and institutional quality assurance systems in the European Higher Education Area, as well as at the level of international cooperation.

Today, numerous structures have been created to monitor the implementation of the tasks, course and development of the Bologna process, in particular: 1) BFUG - Bologna follow-up group; 2) EUA The European University Association (European Universities Association); 3) ESIB - The National Unions of Students in Europe; 4) EURASHE - European Association of Institutions in Higher Education; 5) UNESCO-CEPES - European Center for Higher Education (UNESCO); 6) ENQA - The European Association for Quality Assurance in Higher Education; 7) EIRES - Educational International Pan-European Structure (Educational International PanEuropean Structure); 8) UNICE - Union of Confederations of Industrialists and Employers of Europe (as advisory member).

In 2005, Ukraine joined the Bologna Process, recognizing its position as a priority and topical. By Order of the Minister of Education and Science No. 612 of July 13, 2007, the "Action plan for ensuring the quality of higher education of Ukraine and its integration into the European and world educational community" was approved; A Bologna Process Support Working Group and an interagency group on the implementation of its provisions have been set up. Currently, preparations for the transition to a three-tier system of training specialists are underway; measures are being taken to promote mobility, including 
internships for students and scientific and pedagogical staff; the conclusion of inter-university agreements on the exchange of personnel, the creation of joint training programs for European universities with European universities; the draft of the appendix to the diploma and methodical recommendations for its filling are prepared; the National Qualifications Framework entered into force as a prerequisite for the verification of educational and educational degrees, etc.

\section{SUMMARY}

Finally, modern European university higher education is characterized by a number of constitutional tendencies that reproduce the peculiarities of the modern globalized world. They also concern Ukraine, the development of its higher education systems as an important component of the European educational space. Currently, the main tasks of the reform of the national university education, which are envisaged by the Bologna Process, are: 1) introduction of a three-tire higher education system (bachelor, master, doctor of philosophy); 2) life-long learning, including recognition of prior learning (formal and informal), flexible curricula for the educational process, which combine work and education, and facilitate access to higher education; 3) the guarantee of equal opportunities in education and through the education of the promotion of socialization in a globalized world; 4) promotion of employment (higher education for better work); 5) introduction and recognition of joint educational programs, as well as joint diplomas provided by partner universities; 6) mobility of students and teachers within and outside the EU; 7) recognition of studies, levels and degrees received at universities of other countries and continents; 8) implementation of the system of monitoring and ensuring the quality of higher education.

\section{REFERENCES}

1. Авшенюк Н. Соціально-економічні детермінанти розвитку транснаціональної освіти на зламі XX - XXI століть. Порівняльна професійна педагогіка. 2011. № 1. С. 52-61.

2. Андрущенко В., Молодиченко В. Академічна мобільність : проблема реалізації в Україні і в світі. Вища освіта Украӥни. 2010. № 1. C. 34-42. 
3. Астахова К. В. Вища освіта в умовах сучасного етапу глобалізації : потреба кардинальних змін. Вища освіта України. 2010. Том I (19). Дод. 4. Тематичний випуск «Вища освіта України у контексті інтеграції до європейського освітнього простору». С. 28-34.

4. Бондаренко Е. Н. Профессиональное педагогическое образование в зарубежных странах на современном этапе : монография. Минск : Тесей, 2008. 224 с.

5. Вауліна О. С., Умєрова А. С. Академічна мобільність як складова Болонського процесу. Вища освіта Украӥни. 2010. Том I (19). Додаток 4. Тематичний випуск «Вища освіта України у контексті інтеграції до європейського освітнього простору». С. 61-66.

6. Герасимчук 3. В., Поліщук В. Г. Стимулювання сталого розвитку регіону : теорія, методологія, практика : монографія. Луцьк : РВВ ЛНТУ, 2011. 516 с.

7. Гессен С. И. Основы педагогики. Введение в прикладную философию. Москва: Школа-Пресс, 1995. 447 с.

8. Голубець М. А. Розвиток «сталий» чи «збалансований»? Украӥнський географічний журнал. 2006. № 2. С. 66-69.

9. Гринів Л. С. Екологічно збалансована економіка : проблеми теорії : монографія. Львів: ЛНУ ім. І. Франка, 2001. 240 с.

10. Дмитренко М. Інноваційний розвиток України в контексті впровадження нових знань. Освіта регіону. 2018. № 4. URL: http://social-science.com.ua/ article/633.

11. Дмитриченко М. Ф., Хорошун Б. І., Язвінська О. М. Вища освіта і Болонський процес : навч. посіб. Київ : Знання України, 2006. $440 \mathrm{c}$.

12. Карпенко О. М., Бершадская М. Д. Высшее образование в странах мира: анализ данных образовательной статистики и глобальних рейтингов в сфере образования. Москва : Изд. МГУ, 2009. 244 c.

13. Колесник В. Ю. Освітні програми нового покоління Європейського Союзу як правовий механізм впливу на євроінтеграційні процеси у сфері освіти. Вісник Чернівецького факультету Національного університету «Одеська юридична академія». 2015. № 2. С. 7-17.

14. Корсак К. В. Світова вища освіта. Порівняння і визнання закордонних кваліфікацій і дипломів : монографія / за заг. ред. Г. В. Щокіна. Київ : МАУП-МКА, 1997. 208 с. 
15. Кремень В. Освіта і наука в Україні - інноваційні аспекти. Стратегія. Реалізація. Результати. Київ : Грамота, 2005. 448 с.

16. Кряжев П. В. Структура вищої освіти в країнах Західної Свропи на межі XX - XXI століть. Педагогічний альманах. Херсон, 2008. Вип. 3. С. 177-183.

17. Модернізація системи вищої освіти: соціальна цінність i вартість для України: монографія / Михальченко М. І., Андрущенко В. П., Бульвінська О. І. та ін. Київ: Пед. думка, 2007. 224 с.

18. Огнев'юк В. Філософія освіти в структурі наукових досліджень феномену освіти. Шлях освіти. 2009. № 4. С. 2-6.

19. Про інновації та економіку знань. Міністерство економічного розвитку і торгівлі України. 24 листопада 2015 р. URL: http://new.me.gov.ua/content/pro-innovacii.htm

20. Професійна освіта в зарубіжних країнах : порівняльний аналіз : монографія / за заг. ред. Ничкало Н. Г., Кудіна В. О. Київ : Вибір, 2000. 322 с.

21. Саймон Б. Общество и образование / под. ред. В. Я. Пилиповского. Москва : Прогресс, 1989. 199 с.

22. Сбруєва А. Болонський процес : пошуки шляхів підвищення конкурентоспроможності європейської вищої освіти. Шлях освіти. 2002. № 1. C. 18-21.

23. Сисоєва С. В. Освіта як об'єкт дослідження. Шлях освіти. 2011. № 2. C. 5-11.

24. Скотна Н. Особа в розколотій цивілізації : освіта, світогляд, дії : монографія. Львів : Українські технології, 2005. 384 с.

25. Словник української мови: в 11 т. / ред. кол. І. К. Білодід (голова) та ін. Київ: Наукова думка, 1970 - 1980; Т. 8: П - Р. С. 929.

26. Тараненко І. Г. Нові орієнтації у змісті соціально-політичної освіти європейських країн. Педагогічні інновації : ideї, реалії, перспективи. Київ, 1998. С. 94-98.

27. Терещук Г. В. Зближення освітніх систем : теорія i технологія. Педагогічна $і$ психологічна науки в Украӥні : зб. наук. праць до 15-річчя АПН України у 5 т. Київ : Пед. думка, 2007. Том 1 : Теорія та історія педагогіки. С. 157-165.

28. Фіцула М. М. Педагогіка вищої школи : навч. посіб. 2-е вид., допов. Київ : Академвидав, 2014. 454 с.

29. Хоружий Г. Ф. Вища освіта на шляху оптимізації. Шлях освіти. 2011. № 4. С. 22-27. 
30. European research area (ERA). URL : https://ec.europa.eu/info/ research-and-innovation/strategy/era_en.

31. Mobility for Better Learning. Mobility strategy 2020 for the European Higher Education Area (EHEA). Bucharest Ministerial Conference (2012). URL: http://www.ehea.info/uploads/(1)/ 2012\%20ehea\%20mobilit\%20strateg.pdf.

Information about the author: Orshansky L. V. Doctor of Pedagogical Sciences, Professor, Head Department of Technological and Professional Education, Drogobych Ivan Franko State Pedagogical University 4/6, M. Hrushevsky str., Drohobych, Lviv region, 82107, Ukraine 